\title{
Determinants of Households Saving Capacity and Bank Account Holding Experience in Ethiopia: The Case of Dessie Zuria Woreda
}

\author{
Bazezew Endalew \\ College of Business and Economics, Department of Economics, Wollo University, Dessie, Ethiopia
}

\begin{abstract}
This research has been an attempt to identify the major determinants that affect households saving capacity and their experience of adopting formal financial institutions (banks) in the case of Dessie Zuria Woreda. To do so, an individual base cross-sectional data analysis along with the two stage sampling technique of both purposive and random sampling technique was undertaken. To analyze the data, the study employed two sets of models (logistic and the method of principal component analysis). The econometric results of the study indicates that determinants like lack of credit access, lack of financial planning, complexity of banking system, monthly expenditure on stimulants, sex, significantly and negatively affects households saving capacity, but monthly income, age, bank account holding experience, marital status, and occupation positively and significantly affects saving capacity. In similar fashion, determinants include improper government policy, weak institutional set up, complexity of banking system, distance in $\mathrm{Km}$ away from their home to financial institutions, and religion significantly and negatively affect the probability of households to be banked, on the other hand, sex of households, credit access, income, marital status, education and age positively and significantly affects the probability of households to be banked. It found out that the saving rate of banked households was higher than unbanked households. Thus, appropriate strategies and programs should be formulated to enhance saving rate as well as households tradition of adopting formal financial institutions.
\end{abstract}

Keywords: Principal Components, Kebele, Dessie Zuria Wereda, Household Saving Capacity, banked, unbanked, Saving Determinants.

DOI: $10.7176 / \mathrm{JESD} / 10-5-01$

Publication date:March $31^{\text {st }} 2019$

\section{Introduction}

\subsection{Background of the Study}

Saving is the amount of money left over when the cost of consumer expenditure is subtracted from the amount of disposable income (income after tax) she /he earns in a certain period of time (Keynes J, 1936). It is the proportion of income not spent on current expenditure because a person does not know what will happen in the future, money should be pay for unforeseen events or emergencies. Therefore, saving helps an individual or family become secure in economic or financial matters. According to the classical point of view, saving is one of the major determinants of economic growth, because of the fact that a significant amount of saving enables one country to maintain its efficient financial and capital resource mobilization, as a result, the country becomes more productive in terms of real output and employment opportunity and able to overcome external forces.

According to Elbadawi and Mwega (2000), saving is an important factor to achieve economic growth and development because it helps to change resources in to large investment projects, as a result, it creates permanent job opportunity and real output. They also recognize that in most developing countries, attention is given to foreign saving in the form of capital flows; it results from lack of adequate domestic saving to finance domestic investment.

The empirical findings of Ismaila and Mohammed (2011) found out that the cause for low domestic saving rate in Nigeria is low level of disposable income generated, inadequate saving channels, existence of underdeveloped capital markets, unplanned consumption patterns, unfavorable economic environment characterized by unemployment and inflationary pressure. Therefore, overcoming such problems from the grass root level would solve the lower level of domestic saving rate and investment. Although the government and other corporate sectors play a significant role to bolster domestic saving rate, the contribution of individuals and households is very crucial since it directly helps them in improving their living standard or quality of life (Mayoux, 2015).

According to Genet (2016), the presence of climate change undermines the dynamic growth and development of Ethiopia, due to the fact that if there is volatility in climatic conditions, then fluctuations in income of households will appear, this intern retards households saving capacity. Therefore, the nation is directly looking for foreign aid and capital flows from abroad, this indirectly affects its international competitiveness. Ethiopia is among the developing country which seeks higher level of investment growth; however, her domestic saving rate was the lost for several decades. The average domestic saving rate was about $7.9 \%$ of GDP during 
(1970/71 to 2010/11) (Haile, 2013). Moreover, according to (2011) World Bank report, the average saving rate of Ethiopia was very low by any means of standard. For instance, when compared with the average saving rates of Sub-Saharan African Countries between the period 1980/81 and 2010/11, the average domestic saving rate in Ethiopia was only $8.6 \%$ of GDP, however, during the same period the sub-Saharan African countries was $17.2 \%$ of GDP, this is an indication of the lower level of domestic saving rate of Ethiopia.

Therefore, south Wollo zone of Ethiopia is one of the most well- known areas in its vulnerability to socioeconomic fluctuations and natural disasters like drought and flood, which arises from the volatility nature of agro climatic zone. Because of fluctuations in income of households in this area, their saving capacity is very low (Little and Workeneh, 1998). As a result, the community in this area are highly exposed for sever food insecurity problem, long term unemployment, inadequate standard of living, hanger and disaster, and undeveloped nature of credit and financial institutions, therefore, they are unable to finance the problem. Thus, Dessie Zuria Wereda is located in this zone with a total population of 178,364 out of this 91,719 are males and 86,645 are females (CSA, 2007). The area exhibits different ecological zone and socio-demographic characteristics that experiences fluctuations in various socio economic factors. So that, to overcome the above problem in particular and to ensure the nations sound capital and financial mobilization in general, building of a significant improvement on household saving capacity in Dessie Zuria Woreda (district) would be the possible measurement undertaken by the concerned body.

Moreover, in Ethiopia, the distribution of bank branches and banking services were in adequate until 1990s, as a result, many numbers of the population were financially excluded. However, the number of households who adopt financial institutions increase dramatically following the frequent expansion in bank branches (Haile, 2013). Despite its increment, a number of factors significantly affect households to adopt modern financial institutions, particularly banks. For instance, households' religion, income, consumption patterns, educational level of households-in conceptualizing the risk and return characteristics of asset accumulation, age, and households' sex were assumed to be the possible determinants.

Therefore, this study could be intended to identify the various factors which are expected to affect households saving capacity and their tradition of adopting modern financial institutions.

\subsection{Statement of the Problem}

According to the Debt Sustainability Analysis (DSA), the Ethiopian external debt becomes to peak as a share of GDP in 2017/18, which implies that the present value of external debt increases to $18.8 \%$ of GDP in 2014/15, and reaches $24.5 \%$ of GDP by $2017 / 18$ because of low domestic financial mobility (IMF projection, 2013). Foreign exchange shortage, limited financial options arising from low level of domestic saving was the main difficulties to achieve the growth and transformation agendas. Although, the intensification of Foreign Direct Investment (FDI) has a great importance to the countries socio-economic development, it has also its own demerit in exploitation of resources in a large amount and it diffuses the culture and norms of the society in various aspects so that domestic saving is relevant to overcome this problem (MoFED, 2010). So that it is believed that the pattern of domestic saving particularly individuals saving in the country should change if higher rate of saving is required.

Thus, most researchers who conducted their study on the area of domestic saving in Ethiopia are at the aggregate level, as a result, their analytical framework ignores household heterogeneity by assuming a representative household agent, this macroeconomic standing point were unable to represent real world features that shows the diversity of saving behavior. On the other hand, an individual based analysis allows pointing out the major bottlenecks that retards households saving capacity from the grass root, which is assumed to be a significant determinant of economic growth (Touhami et al., 2009).

Accordingly, this study would have been an attempt to employ a large body of micro econometric based analysis to explore the major determinants of households saving capacity at the grass root level to overcome the problem and paving ways for huge financial and capital mobility. In addition, one major crucial point what makes this study unique on this area is the analytical framework that the researcher intended to use, that is, there are a multiple of factors that have both quantitative and qualitative attributes which affects households saving, and it is not likely to be objectively measurable, to handle such a problem and to extract the most important information required, the researcher was utilized the method of principal component analyses as a supplementary tool of analysis. To the best of the researcher's knowledge, no research of the same type was conducted in the study area.

Therefore, the general objective of this study was to identify the determinants that affect households saving capacity and their bank account holding tradition.

The specific objectives of this study were:

$\checkmark$ To identify the determinants that affect households saving capacity.

$\checkmark$ To investigate the major factors that affects households' bank account holding tradition.

$\checkmark \quad$ To examine the extent of households saving between banked and unbanked households. 
Following such premises, the researcher has been an attempt to address the following question in line with the research objectives:

$\checkmark$ What are the major determinants that affect households' saving capacity?

$\checkmark$ What are the major factors that affect households' bank account holding tradition?

$\checkmark$ How the existing extent of saving between banked and unbanked households does look like?

\section{Methodology of the Study}

\subsection{Description of the study area}

Dessie Zuria district (Woreda) is one of the 105 Woreda in the Amhara region of Ethiopia. Located at the eastern edge of the Ethiopian highlands in the south Wollo zone, it is bordered on the south by were Ilu, on the west by Legambo, on the north west by Tenta, on the north by Kutaber, on the north east by Tehuledere, on the east by kalu, on the south east by oromia zone. It consists of 32 number of kebeles with a population density of 168.22 , which is greater than the zone average of 147.58 persons per square kilometer (CSA, 2007).

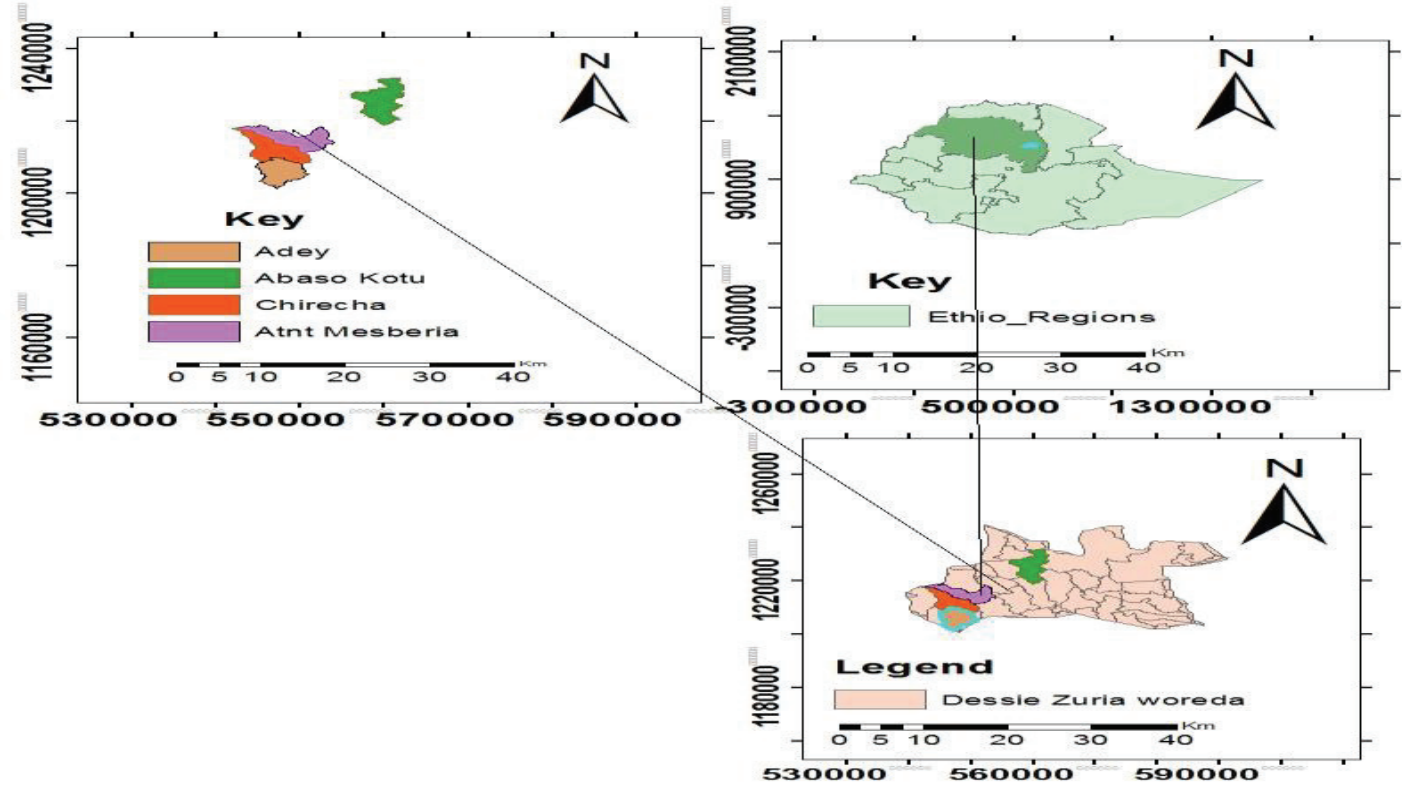

Figure 1.1: Dessie Zuria Woreda Map

Source: Woreda’s Agriculture and Rural Development Office, 2010

\subsection{Data Source and Type}

The data used for this study was obtained from both primary and secondary sources. Here, the nature of the data is cross-sectional type which consists of both quantitative and qualitative information manly from individual bases, for the primary data, the researcher employed both open and closed ended questionnaire and structured interview. The secondary data was extracted from journals, libraries, internets, and from concerned institutions, for example, Amhara Saving and Credit Institution (ASCI) and saving and Credit Cooperatives (SCC) of Dessie Zuria Woreda.

\subsection{Sampling technique and Sample Size}

To determine the relevant sample size of the study, both probability and non-probability (purposive sampling) sampling technique were employed. Therefore, in Dessie Zuria Woreda, there are thirty-two (32) numbers of kebeles $^{1}$ (target population) which experiences different agro-climatic zone. Out of these, the researcher purposively choose fifteen (15) number of kebeles [five (5) of the highest ranking group, five (5) of the middle ranking group, and five (5) of the lowest ranking group] as a sampling unit, provided that such number of kebeles were predetermined groups according to their saving and investing ability. Thus, six numbers of kebeles were proportionally selected from 15 numbers of kebeles.

Consequently, the following statistical formula which is manly applicable for heterogeneous population (krejcie and Morgan, 1970) was utilized to determine the sample households in each kebeles, and it is given by:

$$
n=\frac{Z^{2} p q N}{\ell^{2}(N-1)+Z^{2} p q}
$$

\footnotetext{
${ }^{1}$ Kebeles refers to a certain district specified for administration purpose.
} 
Where, $\mathrm{n}=$ size of the sample;

$\mathrm{N}=2583$, size of the total population of the sampling unit (in 6 kebeles)

$\mathrm{Z}=1.96$, the value of a standard variant at a given confidence level and to be worked out from table showing area under normal curve;

$\mathrm{P}=$ sample proportion of successes $(0.24)$, which is obtained from repeated sampling (prior research reports) of households saving experience on the study area.

$q=0.76(1-p)$, sample proportion of failure; $e=5 \%$, acceptable error, the precision or marginal error between the sample and the population which is mostly applicable in social science research; and hence, $n=253$

Table 2.1: Number of sample kebeles and proportional sample size

\begin{tabular}{lccc}
\hline Name of kebeles & total population $^{1}$ & sample households from each kebele \\
\hline \hline (Cherecha) & 798 & 78 \\
(Atintmesibra) & 544 & 53 & \\
(Berara) & 90 & 9 & \\
(Berara Jerjera $)$ & 388 & 28 & \\
(Abaso kotu) & 220 & 53 & $\mathbf{2 5 3}$ \\
(Adey) & 543 & $\mathbf{2 5 8 3}$ & 22 \\
\hline \hline
\end{tabular}

Source: Saving and Credit Cooperatives in Dessie Zuria Wereda and own computation, 2017/18.

\subsection{Methods of Data Collection}

The main source of data for this study was extracted from primary data source through self-designed questionnaire of both closed and open ended type, a systematic and well-structured interview process with the help of highly standardized technique of recording was utilized. The next set of data source employed in this study was the secondary one, and it was obtained from various written and unwritten sources such as internal reports of Amhara Saving and Credit Institutions (ASCI) and Saving and Credit Cooperatives of Dessie Zuria Woreda (district).

\subsection{Methods of Data Analysis}

The mode of analysis used in this study was undertaken in line with the specific objective of the inquiry. Therefore, the extents of saving between banked and unbanked households were primarily examined through the help of an independent sample t-test technique and factors which are expected to affect households saving capacity and their bank account holding tradition has been analyzed through descriptive and inferential approach. To conduct the analysis, relevant soft ware's (STATA version 16.0 and SPSS version 20.0) was employed as a tool of analysis along with relevant diagnostic tests (normality test, multicolinearity test, hetroscedasticity test, and specification test).

\subsection{Econometric model Formulation}

To address the required objectives of the research, the researcher has been employed two sets of models (logit and Principal Component Analysis). The first set of models employed was that of the limited dependent variable model of binary logistic regression by undertaking the response of households whether they save or not as an outcome variable, it is an econometric model applied when the value of the response variable is measured in a certain probabilistic distribution (Verbeek M, 2004). The method of principal component analysis was also the next set of model utilized in this study.

\subsubsection{Specification of the logit model}

The probabilities of household's response towards save or do not save from a portion of their monthly income subject to different constraints yields a binary dependent variable. As a result, the functional form of the logistic/cumulative distribution function of the response variable conditional to explanatory variables is given by: $P_{i}=E\left(Y=\left.1\right|^{\left.x_{i}\right)=\beta_{1}+\beta_{2} x_{i}}\right.$

$P_{i}=\overline{1+e^{-(\beta 1+\beta 2 X i)}}$

For easy of exposition, we can write equation (2) as;

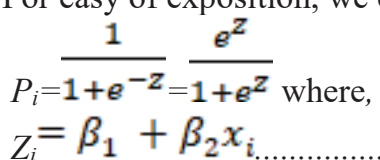

\footnotetext{
${ }^{1}$ Total population refers to the number of people who are grouped under the working age group (18-65 years).
} 
$P_{i}=E\left(Y=\left.1\right|^{x_{i}}\right)$, implies that the probability of a household who save conditional to explanatory variables. If $\mathrm{P}_{\mathrm{i}}$ is the probability of households who save, then 1-

$p_{i}$ becomes the probability of households who do not save. Accordingly,

\section{$P i$}

$1-P i$

(4), is simply the odds ratio in favor of saving, or the ratio of the probability that households who save per those who do not save. If

we take the natural $\log$ of equation 4 , we have:

$L_{i=l(} \frac{p i}{1-p i}$ ), then, $Z_{i}=\beta_{1}+\beta_{2} x_{i}$

here the $\log$ of odds ratio $\left(L_{i}\right)$ is not only linear in the explanatory variables but also the parameters, for estimation purpose, we can write equation(5) as;

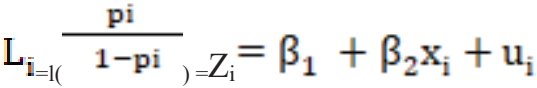

where $\beta^{\prime}$ s are estimated parameters, $X$ 's are explanatory variables, and, $u_{i}$ is stochastic or error terms, and $i=1$, $2,3 \ldots \ldots . n$.

Table 2. 2: description of variables in the model (households saving capacity)

Variable name variable nature description expected impact

$\begin{array}{lccc}\text { saving response (dep) } & \text { dummy } & 1: \text { if they save } & \\ \text { age } & \text { 0: otherwise } & \text {-ve as it increases } \\ \text { income } & \text { continuous } & \text { households age } & \text { +ve as it increases } \\ \text { expenditure on stimu. } & \text { continuous } & \text { monthly income } & \text {-ve as it increase } \\ \text { sex } & \text { continuous } & \text { monthly expenditure on stimulants } & \text { male househo- }\end{array}$

0: otherwise

$s$ are savers

marital status

educational level

year of job experience

occupation

employ

\section{bank account owner}

family size nominal 1:if married

2: single
3: widowed
4: if divorced

ordinal

divorced

1: if > grade 10

2: if < grade 10

3: not educated at all

continuous duration of time in the work place

nominal

1: if government employee

2: if self-employed

+ve for gov.t

\& self-

3: NGO employee

dummy

1: owner

0: otherwise

continuous +ve for married

+ve as it increases

$+v e$

Note: other explanatory variables were extracted in the next chapter by using principal component analysis (PCA).

Analogously, as explained from different literatures, the responsiveness of households towards the use of modern financial institutions relative to traditional saving mechanisms is likely to be the main determinant of households saving capacity, the unbanked characteristics of households not only affects their capacity and extent of saving, but also the amount of cash deposited in modern financial institutions, this intern undermines the ability of financial institutions to lend for their principal borrowers(Deaton, 1992).

Thus, the enhancement of household's capacity of saving along with the adoption of using modern financial institutions in a sustainable manner is an invaluable issue. Therefore, to handle this problem, it is important to find out the possible factors that affect households in adopting modern financial institutions. To do so, the researcher is forced to apply the logistic regression model to the second time in this study due to the binary nature of the dependent variable and its popularity. Accordingly, similar to the above functional specification discussed so far, the model can be specified as:

$P_{i}=E\left(Y=\left.1\right|^{\left.x_{i}\right)=\gamma_{1}+\gamma_{2} x_{i}}\right.$ 


\section{$P_{i}=\frac{1}{1+e^{-\left(\gamma_{1}+\gamma_{2} x_{i}\right)}}$}

For easy of exposition, we can write equation (2) as;

$P_{i}=\frac{1}{1+e^{-z}}=\frac{e^{z}}{1+e^{z}}$ where,

$Z_{i}=\gamma_{1}+\gamma_{2} x_{i}$

$P_{i}=E\left(Y=\left.1\right|^{\chi_{i}}\right)$, implies that the probability of a household who have bank accounts conditional to explanatory variables. If $\boldsymbol{P}_{\boldsymbol{i}}$ is the probability of households who hold bank accounts, then $1-p_{i}$ becomes the probability of households who are unbanked. Accordingly,

$\frac{P i}{1-P i}$

$L_{i=l(} \frac{p i}{1-p i}$, then, $Z_{i}=\gamma_{1}+\gamma_{2} x_{i}$

(5), here the log of odds ratio $\left(L_{i}\right)$ is not only linear in the explanatory variables but also the parameters, for estimation purpose, we can write equation(5) as;

$\left.L_{i=l(} \frac{p i}{1-p i}\right)=Z_{i}=\gamma_{1}+\gamma_{2} x_{i}+u_{i}$

(6), where, $\mathbf{Y}^{\prime}$ is dependent variable and it can be expressed as; $Y_{i=} f(x)=\left\{\begin{array}{c}1: \text { if households have bank account } \\ 0: \text { if households have not bank account }\end{array}\right.$

$\gamma_{s}$ are parameters, $\mathrm{x}$ 's are independent variables, and $u_{i}$ is stochastic terms. Here, one should bear in mind is that the researcher incorporated all explanatory variables listed in table 2.2 for this model with only an addition of variables such as household's religion, access to credit, and banks reliability and/or safety ${ }^{1}$.

\subsubsection{The Method of Principal Component Analysis (PCA)}

The second set of model employed in this study was a Principal Component Analysis (PCA); it is a multivariate technique of analysis used in various disciplines as a variable reduction procedure. In many qualitative aspects of data sets there are multiple numbers of constraints which are related to one another (redundancy) and they are correlated. When such type of problem is confronted, PCA is applicable to reduce redundancy of variables and to extract the most important information from the original variables and to represent it as a set of new orthogonal variables called principal components and to display the pattern of similarity of the observations each other (Hotelling, 1933).

PCA computes new variables called principal components which can be specified as a linear combination of the original variables. The first principal component is required to have the largest possible variance, the second component is computed under the constraint of being orthogonal or non-correlated with the first component and to have the largest possible variance, and the other component is computed likewise, and the value of these new variables for the observation are called factor scores (Manly, 1986). To identify the possible artificial variables or principal components, there are at least four distinct criteria such as, the egienvalue one criterion, the scree test, the proportion of variance accounted for, and the interpretability criteria. However, in PCA analysis one of the most commonly used criterions is the egienvalue one criterion called the Kaiser criterion (Kaiser, 1960). After extracting the components, we could use the component (artificial variable) as explanatory variable in the logistic model discussed so far. Thus, let $C_{i}$ be the number of principal components which is expected to be equal to the number of observed variables, and then we have;

$C_{1=} \beta_{11(} X_{1)}+\beta_{12}\left(X_{2}\right)+\ldots \ldots+{ }_{1 P}\left(X_{P}\right)$

$C_{2}=\beta_{21}\left(X_{1)}+\beta_{22}\left(X_{2}\right)+\ldots \ldots . .+\beta_{2 P}\left(X_{P}\right)\right.$

$C_{i=} \beta_{i 1}\left(X_{1)+} \beta_{i 2\left(X_{2}\right)+\ldots \ldots \ldots . .+} \beta_{i P}\left(X_{p}\right)\right.$

Where, $C_{1=}$ the subject scores on principal component 1.00 (the first component extracted).

$\mathrm{i}=1,2,3$.

..n

$\mathrm{C}_{2}=$ the subject scores on principal component two;

$\beta 1 \mathrm{p}=$ the regression coefficient (or weight) for observed variable $\mathrm{p}$ as used in creating principal component one;

$\beta_{2 p}=$ the regression coefficient (or weight) for observed variable $\mathrm{p}$ as used in creating principal component two;

$\mathrm{Xp}=$ the subjects score on observed variable $\mathrm{P}$

$\mathrm{Ci}=$ the subject scores on principal component, $\mathrm{i}$

$\beta \mathrm{ip}=$ the regression coefficient (component loading) for observed variable ' $\mathrm{p}$ in creating principal

${ }^{1}$ Other explanatory variables were extracted by using PCA in the results and discussion section. 
component i.

Now, one very important thing what we should note here is that a principal component that have large weights or loadings mostly above 0.4 from at least three observed variable in the data table qualifies to be retained for interpretation and further analysis, and it is likely to have larger egienvalue or egienvalue $\geq_{1.00}$ (David, 2009). Unlike an oblique rotation that results correlation among new artificial variables or principal components and difficulty of interpretation, the researcher was choose a varimax rotation ${ }^{1}$, an orthogonal rotation from which its result provides uncorrelated components and they are easy for interpretation.

\section{Results and Discussions}

\subsection{Descriptive Results}

This section primarily examine the descriptive statistics part of the study, from which the predetermined sample size of the study was reduced from 253 to 245 due to the existence of missed data during the time of households survey, however, it is reliable and efficient from the ground that its response rate is about $96.7 \%$ compared to the recommended proportion of $80 \%$ (Visser, 1996). As we can see in table 3.1, the mean monthly income of respondents is about birr 3229.67, it is by far more than the mean monthly income of (birr1473.83) households in North Gondar Zone, Ethiopia (Tsega H, and Yemane, 2014).

Table 3.1: summary of descriptive statistics for some selected variables

\begin{tabular}{|l|l||c|c|c|}
\hline \hline Factors & Mean & standard deviation & Mini & Maxi \\
\hline \hline Average monthly income & 3229.67 & 1084.8 & 900 & 6000 \\
\hline Monthly expenditure on stimulants & 284.73 & 123.65 & 50 & 700 \\
\hline Age of households & 35.18 & 10.77 & 18 & 61 \\
\hline Year of experience in the job & 11.2 & 8.211 & 1 & 26 \\
\hline Family size & 2.7 & 2.091 & 1 & 9 \\
\hline \hline
\end{tabular}

Source: own computation from survey data, 2018

The maximum amount of income generated is birr 6000 and minimum amount of birr 900 . The average age of households in this study is about 35.18 years with a maximum and minimum age of 61 and 18 years respectively, provided that the study considers only those who are above 15 years. Here, we can understand that many number of the sample households are grouped under economically active age group, that is why their average monthly income is likely to be higher than the national average of birr 1522.3 (Aron et al., 2013) . The average family size of sample households is about 2.7 which is lower than the national average family size of five (5) person (CSA, 2010), with a maximum amount of nine (9).

\subsubsection{Extents of Saving Between Banked and Unbanked Households}

To verify whether there is significant difference in average saving of banked and unbanked households, an independent sample t-test technique was utilized here. Thus, a sample of 100 households (50 of bank account holders and 50 of unbanked households) are randomly taken from the already working samples of 245 households' for estimation purpose. Therefore, with regard to the extent of saving between banked and unbanked households of table 3.2 below, the average saving of banked households is about birr 996.4 per month, while those of unbanked contour parts is about birr 810.66 per month.

Table 3.2: Extents of Saving Between Banked and Unbanked Households

\begin{tabular}{|c||l||c||c||c|}
\hline Groups of households & Mean & Standard deviation & Number of observation & Sig (at 1-tailed) \\
\hline Banked & 996.40 & 375.13 & 50 & \multirow{2}{*}{0.034} \\
\hline Unbanked & 810.66 & 389.68 & 50 & 0.03 \\
\hline
\end{tabular}

Source: own computation from survey data 2018.

Therefore, at $95 \%$ confidence interval of the difference, we reject the null hypothesis because of the pvalue of 0.034 at 1 -tailed (acceptable in our case) distribution is less than the significance level of 0.05 . Thus, the average saving amount of banked households is greater than unbanked households by birr 185 . 74 . We can also prove that the variation (standard deviation) of the average saving between banked households is less than that of the variation in the average saving between unbanked households. This is an indication of the more probability of consistency in monthly saving rate between households, if they adopt formal financial institutions than traditional saving mechanisms.

\subsection{Econometric Results}

\subsubsection{Application of Principal Component Analysis on Factors Affecting Households Saving Capacity}

As we have discussed so far, due to the behavioral nature of households saving characteristics, it is unlikely to address all the potential factors which are assumed to be affect households saving capacity. Therefore, PCA is

\footnotetext{
${ }^{1}$ A rotation is a linear transformation that is performed on the factor solution for the purpose of making the solution easer to interpret.
} 
used as a data reduction technique of extracting the most potential constraints (components) of affecting households saving capacity. As a result, out of the total fifteen (15) numbers of variables, only seven (7) potential components are extracted in accordance with their respective strong explanatory power of the variation among the original set of variables, and these factors are extracted through the help of Kaiser normalization criteria of an eigenvalue greater than one (1.00) (Kaiser, 1960).

In line with this scenario, the already retained seven components has a cumulative variance of $58.5 \%$, this implies that $58.5 \%$ of the variation in the original set of variables can be explained by the combined effect of these principal components or factors. Moreover, as we can see in table 3.4, each consecutive principal component has their own share on explaining the variance in the data set and accounts $10 \%, 9.5 \%, 8.5 \%, 8 \%$, $8 \%, 7.5 \%$, and $6.8 \%$ respectively. That is the first principal factor explains $10 \%$ of the variance in the data set, the second principal factor explains $9.5 \%$ of the variance in the data set, and likewise the remaining components are interpreted accordingly.

Communalities: It refers to what extent the potential factors are jointly able to represent the variation of each variable in the data (15 variables). Accordingly, as indicated in (table A.2, in appendix A), the extraction section of communalities is very important, so that for the first variable "lack of loan services and incentives" all the retained seven components explains $64 \%$ of its variance, and they also accounts $66 \%$ for the variance of the second variable "lack of collateral", the same is true for other variables.

Loadings of principal components: they are an indication of correlation between the original set of variables and the newly extracted variables; they are derived from the joint or combined effect of two or more original variables to create one artificial variable. It is natural that variables which loads or contributes more than 0.4 for a particular component are assumed to be derived from a certain qualitative attributes, and they are in a tendency to load more for that particular attribute or principal component and less for the other (Hoteling, 1933).

Table 3.4: Component Loading Matrix of Constraints of Saving Capacity(varimax)

\begin{tabular}{|c|c|c|c|c|c|c|c|}
\hline Principal components & 1 & 2 & 3 & 4 & 5 & 6 & 7 \\
\hline Egienvalue & 1.516 & 1.432 & 1.282 & 1.215 & 1.171 & 1.131 & 1.02 \\
\hline $\begin{array}{l}\text { Percentage of variance explained } \\
\text { Constraints }\end{array}$ & $\begin{array}{l}10.105 \\
\text { Lack of } \\
\text { access } \\
\text { to credit }\end{array}$ & $\begin{array}{l}9.547 \\
\text { weak } \\
\text { Infrastructural } \\
\text { services }\end{array}$ & $\begin{array}{l}1.5 \\
\text { improper } \\
\text { gov.t } \\
\text { policy }\end{array}$ & $\begin{array}{l}8.1 \\
\text { pessimistic } \\
\text { view of } \\
\text { households }\end{array}$ & $\begin{array}{c}7.8 \\
\text { weak } \\
\text { institutional } \\
\text { setup }\end{array}$ & $\begin{array}{l}7.5 \\
\text { lack of } \\
\text { financial } \\
\text { planning }\end{array}$ & $\begin{array}{l}\mathbf{6 . 8 4 2} \\
\text { complexity } \\
\text { of banking } \\
\text { system }\end{array}$ \\
\hline Lack of loan services and incentives & .721 & .051 & .047 & -.092 & .101 & .053 & .059 \\
\hline Lack of collateral & -.569 & .264 & .008 & -.102 & .046 & .152 & -.099 \\
\hline $\begin{array}{l}\text { Lack of infrastructural } \\
\text { services(road,electrity,water) }\end{array}$ & .100 & .689 & -.102 & -.152 & .032 & .041 & -.126 \\
\hline $\begin{array}{l}\text { Lack of adequate health and educational } \\
\text { services }\end{array}$ & .228 & -.577 & -.097 & -.137 & -.067 & .143 & -.047 \\
\hline Absence of accountability and transparency & .308 & .083 & .761 & -.005 & -.037 & .091 & -.011 \\
\hline Prevalence of corruption and rent seeking & -.363 & -.120 & .674 & -.077 & -.007 & -.101 & .058 \\
\hline $\begin{array}{l}\text { Use of planning to the future is not important } \\
\text { because god knows the future }\end{array}$ & .048 & .145 & .070 & -.666 & .309 & .249 & -.015 \\
\hline $\begin{array}{l}\text { Enjoying with friends is good no matter how } \\
\text { much money is spent }\end{array}$ & -.076 & -.032 & -.133 & .637 & .336 & .238 & .191 \\
\hline $\begin{array}{l}\text { Religious disciplines prohibit households } \\
\text { saving and investment }\end{array}$ & .269 & .216 & .394 & .536 & -.046 & .083 & -.323 \\
\hline $\begin{array}{l}\text { Lack of well-designed programs of } \\
\text { experience sharing and social networking }\end{array}$ & -.053 & .025 & .162 & -.118 & .767 & -.108 & -.026 \\
\hline $\begin{array}{l}\text { Strategies and programs do not follow a } \\
\text { system of community based approach }\end{array}$ & .128 & .041 & -.232 & .074 & .556 & -.018 & -.093 \\
\hline $\begin{array}{l}\text { Almost half of my monthly income is spent } \\
\text { for stimulants }\end{array}$ & -.215 & -.244 & .012 & .097 & .105 & .711 & .067 \\
\hline Giving money to a friend is always important & -.146 & -.134 & -.007 & .094 & .262 & -.689 & .066 \\
\hline $\begin{array}{l}\text { Difficulty of using electronic systems of } \\
\text { banking services }\end{array}$ & .239 & -.154 & -.006 & .087 & -.073 & .000 & .756 \\
\hline Unable to know account opening requirement & -.115 & .310 & .071 & -.064 & -.082 & .010 & .575 \\
\hline
\end{tabular}

To conduct such analysis, unlike an oblique rotation that gives correlated components and difficulty of interpretation, an orthogonal rotation ${ }^{1}$ (varimax) that provides a relatively exact loading of variables to create new components which are uncorrelated each other as well as expected to yield higher variance or egienvalue and also retained for further analysis as a potential constraint (it will be used to the subsequent regression analysis) were carried out.

Extracted principal components: Once the potential principal components are determined, it is better to naming these factors in accordance with the nature of the original variables developed so far. If a given factor is derived

${ }^{1}$ Other orthogonal rotation methods such as quartimax, equamax, and promax techniques might be utilized as a supplementary tool of analysis. 
from variables which have similar characteristics in their nature, then naming of new artificial variables should be highly associated with these items of having similar attributes. For instance, the first component in this study (table 3.4) is derived from two variables (lack of loan services and lack of collateral) and jointly generates a new variable "lack of access to credit"; the second component is also extracted from the blend of two original variables (lack of infrastructural services like road, electricity, water etc... and inadequate health services), as a result, the second component is named as "weak infrastructural services". In the same fashion for the third component, variables like absence of accountability and transparency; and prevalence of corruption and rent seeking generates a principal component "improper government policy", likewise the remaining principal components are named as "pessimistic attitude of households towards saving"; "weak institutional set up"; "lack of financial planning"; and complexity of banking system" for the $4^{\text {th }}, 5^{\text {th }}, 6^{\text {th }}$, and $7^{\text {th }}$ principal components respectively. Thus, the researcher used these components in the next set of logistic regression model of investigating the determinants of households saving capacity and their tradition of bank account holding experience in a detailed manner.

\subsubsection{Determinants of households saving Capacity}

As we can observe from table 3.5, a total of 245 households are undertaken as a sample observation. Potential constraints considered in the regression analysis were jointly significant to affect the probability of households saving capacity at $1 \%$ level of significant (prob $>$ chi $2=0.000$ ). With regard to individual significance test, out of 21 explanatory variables, thirteen(13) variables are statistically significant at $1 \%, 5 \%$, and $10 \%$ level of significance, which includes monthly income, monthly expenditure on stimulants, sex of households, age, year of job experience, bank account holding tradition, marital status of being single, households occupation of being government employee and self-employed, educational level of households being uneducated, and the remaining variables are extracted principal components which are lack of access to credit, lack of financial planning, and complexity of banking system. To identify the extent to which each variable affects the probability of households saving capacity, it is better to concentrate on the marginal effect segment of logit estimates. As a result, on average, the probability of households saving capacity is increased by $0.025 \%$ as individuals monthly income is increased by one birr. It is consistent with the findings of Yonas and Gebrekrstos (2016).

As far as households sex is concerned, it is a significant determinant of saving, revealed that on average, male households affect the probability of saving capacity by $5 \%$ less than that of female counterparts, because in many developing countries like Ethiopia, the possibility of women to be involved outside the family affaires is not adopted and acceptable, so that, they may not be exposed for further expenditure, hence, it results higher saving. However, it contradicts with the findings of Bersales \& Mapa (2006) indicates that male households have better saving performance because females have no power to control income even their own income in most developing countries. Ages of households were found to be a significant and positive determinant of households saving capacity at $1 \%$ significant level. As it is reported in table 3.5 , as households age is increased by one year, on average, the probability of saving capacity of households is increased by $2.6 \%$. However, age negatively and significantly affects households saving capacity because of diminishing marginal productivity ((Aroen et al., 2013) 
Table 3.5: Logit Estimates of Households Saving Capacity

\begin{tabular}{|c|c|c|c|c|}
\hline \multirow[t]{2}{*}{ Variables (constraints) } & \multicolumn{2}{|c|}{$\begin{array}{c}\text { Case(I): } \\
\text { Logit estimates }\end{array}$} & \multicolumn{2}{|c|}{$\begin{array}{l}\text { Case (II): the marginal } \\
\text { effect after logit }\end{array}$} \\
\hline & Coefficients & $\begin{array}{l}\text { Standard } \\
\text { error }\end{array}$ & Coefficients & $\begin{array}{l}\text { Standard } \\
\text { error }\end{array}$ \\
\hline Monthly income(income) & .0010135* & .000174 & $.000253 *$ & .00004 \\
\hline $\begin{array}{l}\text { Monthly expenditure on stimulants } \\
\text { (mexp) }\end{array}$ & $-.0023833 * * *$ & .0013225 & $-.0005949 * * *$ & .00033 \\
\hline Sex of households (sex) & $-.2141389 * *$ & .3156858 & $-.0533916^{* *}$ & .07854 \\
\hline Age of household (age) & $.1055073 *$ & .0333618 & $.0263346^{*}$ & .00833 \\
\hline Year of job experience(yexp) & $-.1186278^{*}$ & .0383041 & $-.0296095^{*}$ & .00957 \\
\hline Bank account holding tradition(bak) & $.4145324 * *$ & .3190699 & $.1031536 * *$ & .07888 \\
\hline Family size (fams) & -.1885038 & .144489 & -.0470505 & .03605 \\
\hline Married (marsdummy1) & .2185411 & .4520912 & .0543686 & .11194 \\
\hline Single(marsdummy2) & $.1134813 * * *$ & .4877369 & $.028278 * * *$ & .12128 \\
\hline Widowed (marsdummy3) & .3053108 & .4678496 & .0757457 & .11501 \\
\hline Gov.et employee(occodummy1) & $.8997689 * *$ & .4433938 & $.2189102 * *$ & .10328 \\
\hline Self-employed(occodummy2) & $.747449 * * *$ & .4349672 & $.1838513 * * *$ & .10424 \\
\hline $\begin{array}{l}\text { Educated below grade } \\
\text { ten(edudummy2) }\end{array}$ & .1675548 & .3929382 & .0417705 & .09778 \\
\hline Not educated at all(edudummy3) & $-.528544 * *$ & .4226519 & $-.1304248 * *$ & .10234 \\
\hline Lack of access to credit(lacc) & $-.270615 * * *$ & .1600269 & $-.0675455 * * *$ & .03994 \\
\hline Weak infrastructural services(wis) & .0136723 & .1544686 & .0034126 & .03856 \\
\hline Improper government policy(imgp) & -.1577622 & .1554227 & -.0393774 & .03881 \\
\hline $\begin{array}{l}\text { Pessimistic view of households } \\
\text { towards saving(pvh) }\end{array}$ & -.05714 & .1552703 & -.0142621 & .03876 \\
\hline Weak institutional setup (weis) & -.1196545 & .1544274 & -.0298657 & .03854 \\
\hline Lack of financial planning(lfp) & $-.027121 * * *$ & .1547989 & $-.0067694 * * *$ & .03864 \\
\hline Complexity of banking system(cbs) & $-.22052 * *$ & .1608158 & $-.0550418 * *$ & .04013 \\
\hline Constants & $-6.891354^{*}$ & 1.327121 & & \\
\hline
\end{tabular}

Source: own computation from survey data, 2018

With regard to households marital status, marital status of being married and widowed not significantly affect households saving capacity, however, ceteris paribus, single households increases the probability of saving capacity by $2.9 \%$ more than that of divorced.

Households occupation were found to be a significant determinant of saving capacity at a $5 \%$ and $10 \%$ significance level for both government employee and self-employed households respectively. This implies that ceteris paribus, being government employee and self-employed households' affects the probability of households saving capacity by $22 \%$ and $18 \%$ more than that of NGO employees respectively. The reason is mostly attributed to the nature of income generated by the respective type of job that households engaged. For government employee, the amount of income generated is highly consistent for a certain period of time, although it is not a continuous phenomenon because of retirement. Moreover, being a government employee is also an indication of households' financial literacy, regardless of their level of education. Implies that government employees are most likely to have positive attitude towards saving, even not only aware of the importance of saving, but also they are smart enough in making cost benefit analysis by considering the risk and return characteristics of different assets in this uncertain world (Zhang et al., 2003). Unlike the variability of income, most self-employed households generate more income over time because of economies of scale arising from economically active age group within their family, particularly for the agrarian Ethiopian societies and generate more income, it results higher levels of saving.

Ceteris paribus, households educational level of being uneducated affects the probability of saving capacity by $13 \%$ less than that of households who completed secondary education and above. This is because of the fact that educated households are more responsive to save and invest from their part of income; since they are expected to be financially literate and lead their life in a responsible manner than those who are not educated at all, it is similar with the findings of (Cole S, and Shasry K, 2007) revealed that educated households significantly affects saving capacity because of financial literacy. Potential constraints constructed from the method of 
principal component analysis were included under the regression analysis. Therefore, out of seven components (lack of access to credit; lack of financial planning; complexity of banking system; weak infrastructural services; improper government policy; pessimistic view of households towards saving; and weak institutional set up) only the first three components are statistically significant. Thus, the shallow nature of credit access arising from complex prerequisite borrowing schemes (lack of collateral) and absence of loan services and incentives undermine households saving and investing capacity by about 0.067 . Because of the complexity of banking system, households are forced to save in traditional institutions like "idir" and "Iquib" in an infrequent or irregular manner, as a result, not only the probability of households saving capacity is negatively affected (0.055), but also it affects the ability of financial institutions to mobilize cash and other assets, since huge financial resources are deposited in traditional institutions. Sample households planning experience, particularly in financial matters is not encouraged. Therefore, it negatively affects the probability of households saving capacity.

\subsubsection{Determinants of Households Bank Account Holding Tradition}

This section manly investigate the potential factors that affect households bank account holding experience through employ a binary logit model of considering whether households have a bank account or not as an outcome variable conditional to different explanatory variables. As it is indicated in table 3.6, explanatory variables undertaken in the regression analysis were jointly significant to affect the probability of households' bank account holding experience at a $1 \%$ level of significance (prob $>c h i^{2}=0.0057$ ). On the other hand, with regard to individuals' significance test, out of 25 potential constraints, fourteen (14) variables are statistically significant at $1 \%, 5 \%$, and 10\% level of significance. Accordingly, monthly income of households significantly and positively affects the probability of households to be banked by about $0.06 \%$ ceteris paribus, because as income increases, households are inspired to save and invest. As we can see in table 3.6, households' sex affects the probability of bank account holding experience at $5 \%$ level of significance. This implies that ceteris paribus, being male households affects the probability of bank account holding experience by $7 \%$ more than that of female households.

households age was found to be significant at 5\% and positively affects household's bank account holding experience in the short run, but in the long run (age square, table 3.6) other things remaining the same, as age increases the probability of households being banked is decreased by $0.06 \%$. This is because as long as households are old aged, they are less likely to save and invest, results from their economically inactive age group and they are unlikely to be banked. The other positive and significant determinant of households' bank account holding experience is the nature of credit access. That is, other things remaining the same, the presence of enough credit access increases the probability of households to be banked by $23 \%$ more than if there is no access to credit. If there is credit access, households are motivated to use modern financial institutions, it in turn increases saving and investment by bolstering the amount of financial mobility, employment opportunity, and real output creation (Deaton, 1992).

Distance $(\mathrm{km})$ from households' house to financial institutions is a significant determinant of bank account holding tradition at $10 \%$ significance level in the short run. Therefore, as long as households are far from the location of financial institutions, they are less likely to be bank account holders, so that on average, the probability of households to be banked is decreased by $0.57 \%$ as distance increases by one $(1 \mathrm{~km})$, although it is insignificant in the long run (Distance square, see table 3.6). Only marital status of being single is statistically significant at 5\%. This implies that ceteris paribus, single household affects the probability of household's to be banked by $8 \%$ more than married households. It is due to the fact that no matter the amount of saving is, single households are willing to use modern financial institutions, and it is consistent with the findings of (Touhami et al., 2009).

\footnotetext{
${ }^{1}$ Idir and Iquib are the Ethiopian version of representing traditional saving mechanisms.

The reliability of variables in the model was tested through the help of cronbach alpha $(\geq 0.7)$, therefore, in this study the cronbach alpha value of variable is about 0.78 , as a result, the reliability test is proved to be statistically significant.
} 
Table 3.6: Logit Estimates of Households Bank Account Holding Tradition

\begin{tabular}{|c|c|c|c|c|}
\hline \multirow[b]{2}{*}{ Variables (constraints) } & \multicolumn{2}{|c|}{$\begin{array}{l}\text { Case(I): } \\
\text { Logit estimates }\end{array}$} & \multicolumn{2}{|c|}{$\begin{array}{l}\text { Case (II): the marginal } \\
\text { effect after logit }\end{array}$} \\
\hline & Coefficients & $\begin{array}{l}\text { Standard } \\
\text { error }\end{array}$ & Coefficients & $\begin{array}{l}\text { Standard } \\
\text { error }\end{array}$ \\
\hline Monthly income(income) & (.0023495* & 2.0007592 & .0005834* & .00019 \\
\hline $\begin{array}{l}\text { Monthly expenditure on stimulants } \\
\text { (mexp) }\end{array}$ & -.0018924 & .0012555 & -.0004699 & .00031 \\
\hline Sex of households (sex) & $.2926415 * *$ & .2959908 & $.0725606 * *$ & .07318 \\
\hline Age of household (age) & $.212978 * *$ & .1018015 & $.0528823 * *$ & .02527 \\
\hline Access to credit(acc) & $.9631957^{*}$ & .299807 & $.2355971^{*}$ & .07077 \\
\hline Family size (fams) & -.0498794 & .1275195 & -.012385 & .03166 \\
\hline $\begin{array}{l}\text { Distance in } \mathrm{km} \text { from their house to } \\
\text { financial institutions(dis) }\end{array}$ & $-.0230763 * * *$ & .0398545 & $-.0057298 * * *$ & .0099 \\
\hline Banks safety or trust(safty) & -.1033942 & .3001455 & -.0256595 & .07443 \\
\hline Single(marsdummy2) & $.3466752 * *$ & .414536 & $.0850705 * *$ & .10009 \\
\hline Widowed(marsdummy3) & -.39027 & .3889548 & -.0971283 & .0965 \\
\hline Divorced(marsdummy4) & -.2928839 & .4290945 & -.0729815 & .1069 \\
\hline Muslim(relidummy1) & -.0326686 & .3425868 & -.0081112 & .08505 \\
\hline $\begin{array}{l}\text { Others or catholic and } \\
\text { protestant(relidummy } 3 \text { ) }\end{array}$ & $-.5797795 * *$ & .426051 & $-.1439357 * *$ & .10428 \\
\hline $\begin{array}{l}\text { Educated above grade } \\
\text { ten(edudummy1) }\end{array}$ & $.0938201 * * *$ & .3842453 & $.0232454 * * *$ & .09497 \\
\hline $\begin{array}{l}\text { Educated below grade } \\
\text { ten(edudummy2) }\end{array}$ & .5613882 & .3431162 & $.1389734 * * *$ & .08409 \\
\hline Distance square(dis2) & -.0005496 & .0006275 & -.0001365 & .00016 \\
\hline Age square(age2) & $-.0024078 * * *$ & .0012732 & $-.0005979 * * *$ & .00032 \\
\hline Income square(micome2) & $-.016 \mathrm{e}-07 *$ & $1.10 \mathrm{e}-07$ & $-.0850508 *$ & .00000 \\
\hline Lack of access to credit(lacc) & -.1873733 & .1504295 & -.0465247 & .03736 \\
\hline Weak infrastructural services(wis) & .1120723 & .1454606 & .0278275 & .03613 \\
\hline Improper government policy(imgp) & $-.1904538 * *$ & .1465809 & $-.0472896 * *$ & .03638 \\
\hline $\begin{array}{l}\text { Pessimistic view of households } \\
\text { towards saving(pvh) }\end{array}$ & .0240918 & .144495 & .005982 & .03588 \\
\hline Weak institutional setup (weis) & $-.0606212 * * *$ & .1464276 & $-.0150522 * * *$ & .03636 \\
\hline Lack of financial planning(lfp & -.0002391 & .1455165 & -.0000594 & .03613 \\
\hline Complexity of banking system(cbs) & $-.2565885 * * *$ & .1458967 & $-.0637108 * * *$ & .03621 \\
\hline Constants & $-7.641941 *$ & 2.395679 & & \\
\hline
\end{tabular}

Source: own computation from survey data, 2018.

Similarly, some of the retained principal components are statistically significant along with their expected sign at 5\% and 10\% significance level. Therefore, the presence of improper government policy negatively affects $(0.047)$ the probability of households to be banked. On the other hand, due to the existence of weak institutional linkage in the process of enhancing households saving and investing capacity, the probability of households to be banked is negatively (-0.015) affected. The complexity of banking system has also its own significant and negative impact on the probability of bank account holders as well as their saving capacity. Moreover, the presence of complexity of banking system has a strong impact on the probability of saving capacity followed by improper government policy and weak institutional set up.

Diagnostic Tests

Hetroscedasticity Test: To check whether the estimated values of the regression results are efficient and reliable, it is better to test the usual OLS assumptions (Verbeek, 2004). Therefore, the conditional distribution of stochastic terms given the regression matrix should have zero mean and constant variance (homoscedastic). As a result, the Breusch Pagan/Cook-Weisberg test for hetroscedasticity technique were employed, it reveals no hetroscedasticity problem, because the researcher is failed to reject the null hypothesis of constant variance at a $5 \%$ significance level along with ( $\mathrm{prob}>\mathrm{chi}^{2}=0.1038$ and $\left.\mathrm{chi}^{2}(1)=265\right)$.

Mullticolinearity Test: The problem of mullticolinearity arises when there is correlation among explanatory variables included in the model; it yields an inefficient and biased estimator of the sample parameters (Verbeek, 
2004). Thus, the researcher utilized the variance inflation factor (VIF) as a checking mechanism of mullticolinearity problem. So that, the mean VIF value of variables in this model is about 1.65 , which is less than ten-the standard and recommended estimated value of mullticolinearity test (Gujarati N, 2004). In addition to this, the correlation coefficient between each variable is below 0.8 ; hence, mullticolinearity problem is not occur. Specification Test: According to Ramsey RESET test technique of omitted variable problem, we have the hypothesis that:

Ho: Model has no omitted variables

$\mathrm{F}(3,219=12.8$

Prob $>F=0.05425$, since $p$-value of $0.05423>0.05$ ( ig level), we are failed to reject the null hypothesis, implies that the model is correctly specified.

Normality Test: To test whether variables in the model are normally distributed or not, the Shapiro-wilk W test technique of normal data were employed, thus;

$\mathrm{Ho}=$ Variables are normally distributed, such that $\operatorname{prob}>\mathrm{z}=0.0622$, which is greater than the level of significance $(5 \%)$. As a result, we can conclude that the model is normally distributed.

\section{Conclusion and Recommendation}

\subsection{Conclusion}

In many developing countries, especially the sub-Saharan Africa (from which Ethiopia is not unique to the region) has been recognized as having insufficient growth in saving rates. It was due to the low domestic saving capacity and household's poor experience to adopt modern financial institution's (banks) (Zhang et al., 2003).

Therefore, the aim of this study was to identify the major factors that affect households saving capacity and their bank account holding tradition in Dessie Zuria Woreda, Ethiopia, mainly from microeconomic grounds. Accordingly, a sample of 253 households was undertaken, provided that only 245 actual observations were employed during the time of estimation. To analyze the data, the Limited Dependent Variable model of binary logistic regression and the multivariate technique of analysis (principal component analysis) were utilized.

Therefore, through PCA, seven (7) potential constraints or components was extracted, interpreted, and used as an explanatory variable for the two regression equations. Thus, for the $1^{\text {st }}$ regression equation of identifying the determinants of households saving capacity, out of 21 explanatory variables, only thirteen (13) variables were statistically significant at $1 \%, 5 \%$, and $10 \%$ level of significance. These significant variables which affect saving capacity positively includes monthly income, age, households bank account holding experience, marital status of being single, and households occupation of being government employee and self-employed. The remaining significant variables such as monthly expenditure on stimulants, sex of being male households, year of job experience, educational level of being uneducated, as well as extracted principal components like lack of credit access, lack of financial planning, and complexity of banking system negatively affects households saving capacity.

For the second set of logit estimates which was employed to identify the bank account holding tradition of households, explanatory variables undertaken in the regression analysis were jointly significant to affect the probability of households' bank account holding experience at a $1 \%$ level of significance ( $\operatorname{prob}>\mathrm{chi}^{2}=0.0057$ ). On the other hand, with regard to individuals' significance test, out of 25 potential constraints, only 14 variables are statistically significant at 1\%,5\%, and $10 \%$ level of significance, which includes monthly income of households, sex of households, age, access to credit, distance from their house to financial institutions, marital status of being single, religion of being catholic and protestant, households educational level who completed above grade ten and below grade ten, age square, income square, improper government policy, weak institutional set up, and complexity of banking system, provided that the last three constraints are derived from extracted principal components. Moreover, the study also found out that those who own bank accounts have good saving and investing capacity relative to others.

\subsection{Recommendation}

Income is found to be the most important determinants of households saving capacity, hence, relevant strategies should be designed; for instance, creation of permanent job opportunity and increase wage rates.

According to the survey result, most households have had pessimistic view about the importance of saving and investment, so that better strategies and training programs should be designed to change society's attitude. Responsible authorities should enhance educational quality and households' financial literacy so as to equip them to know the risk and return characteristics of their asset and the importance of investment.

Since adoption of modern financial institutions (banks) increase the levels of saving as well as utilization of resource, awareness creation through training and experience sharing in a system of community based approach is an invaluable issue. 


\section{Reference}

Aron, H., Negus, A., and Getnet, B. (2013).Assessment of Saving Culture Among Households in Ethiopia. Journal of Economics and Sustainable Development, 2013.4(13). Mekele University, Mekele, Ethiopia

Bersales, S., and Mapa ,D. (2006) .Determinants of household Saving in the Philippines. EMERGE A GRP Project Supported by USAID, Unpublished Technical Report by Bangko Central ng Philippines, (BSP).

Beverly., Sherraden, M.,Zhan, M., Shanks W.T., and Nam. (2008). Determinants of Asset Building; a Report in the Series Poor Finance: Asset and Low Income Households. Central for Social Development Washington University in St. Louis and Reid Cramer New American Foundation.

Central Statistical Agency (CSA). (2010). FDRE General Country Data, 2010.

Central Statistical Agency Report: The 2007 Population and Housing Census of Ethiopia, Addis Ababa, Ethiopia.

Cole,S, and Shastry,K. (2007). If you are So Smart, Why aren't reach?: The Effect of Education, Financial Literacy, and Cognitive Ability on Financial Market Participation. Harvard Business School and Department of Economics, Harvard University.

David, L. (2009). A Practical Guide to Scientific Data Analysis, UK.

Deaton, A. (1992). Understanding Consumption, Oxford, Oxford University Press.

Elbadaw, I., and Mwega, F. (2000). Can Africa's Savings collapse be Reversed? World Bank Economic Review, 14(3): 415-14.

Genet, A. (2016). Determinants of Domestic Private Saving in Ethiopia: Marketing and Cooperative Planning Department.

Gujarati,N. (2004). Basic Econometrics, fourth edition.

Haile, A. (2013). Determinants of domestic saving in Ethiopia: An autoregressive distributed lag model (ARDL) bounds testing approach. Journal of Economics and International Finance, department of Economics, Jimma University. P.O. Box .378, Jimma, Ethiopia

Hotelling, H. (1933). Analysis of a Complex Statistical Variables in to Principal Components. J Educ Pschol 1933, 25:417-441.

IMF. (2013). "The Federal Democratic Republic of Ethiopia”; IMF Country Report No, 13/308.

Ismaila.Mohammed., Imoughele., and Lawrence, E. (2011). An Econometric Analysis of the Determinants of Private Domestic Saving in Nigeria (1981-2012).Ambrose Alli University,Ekpoma Nigeria. International Journal of Humanities and Social Science: Vol, 4, No, 5; March 2014.

Kaiser, H.F. (1960). The Application of Electronic Computers to Factor Analysis. Educational and Psychological Measurement, 20,141-151.

Keynes, J. (1936) .The General Theory of Employment, Interest, and Money. London.

Little, D., and Workeneh N. (1998). Addressing Food Security in the horn of Africa and Central America. Research project, Broadening Access and strengthening input market systems collaborative research support program. Bahir Dar, Ethiopia.

Manly,B. (1986). Multivariate Statistical Methods: A Prime. Champan and Hall, London.March. 2013.

Mayuox, L. (2015). Micro Finance and the Empowerment of Women"; A Review of the Key Issues; Accessed on August 28, 2015.

MoFED. (2010): "Growth and Transformation Plan (GTP) Draft"; Ministry of Finance and Economic Development, Addis Ababa.

Touhami, A., Florence, A., Najat, E., and Sabine, M. (2009) .A Micro-econometric Analysis of Households Saving Determinants in Morocco. African Review of Money Finance and Banking, 2010, pp, 7-27.

Tsega, H, and Yemane, M. (2014). Determinants of household saving in Ethiopia: A case of North Gondar Zone, Gondar University, Gondar, Ethiopia. International Journal of Development and Economic Sustainability. Vol.2, No.4,pp. 37-49, October 2014.

United Nation Human Development Report, 2015.

Verbeek, M. (2004). A Guide to Modern Econometrics; Second edition, Erasmus University Rotterdam, John Wiley and Sns, Ltd.

Visser, A. (1996). Mail Surveys for Election Forecasting? An Evaluation of the Colombia District Poll.Public Opinion Quarterly. 60:181-227.

Yonas, A and Gebrekrstos, G. (2016). Utilization of and Factors Affecting Individual Saving in Ethiopia: International Working Paper Series No.16/02.

Zhang, Z., Zhang, L., and Lee, R. (2003). Rising Longevity, Education, Saving, and Growth. Journal of Development Economics 70:83-101. 


\section{Appendix A:}

Table A.1: Total Variance Explained by the retained (seven) components and trivial components

\begin{tabular}{|c|c|c|c|c|c|c|c|}
\hline \multirow[t]{2}{*}{ Component } & \multicolumn{3}{|c|}{ Initial Egienvalue } & \multicolumn{3}{|c|}{ Extraction Sums of Squared Loadings } & \multirow{2}{*}{$\begin{array}{l}\text { Rotation } \\
\text { Sums of } \\
\text { Squared } \\
\text { Loadings } \\
\text { Total }\end{array}$} \\
\hline & Total & $\begin{array}{c}\% \text { of } \\
\text { Variance }\end{array}$ & Cumulative $\%$ & Total & $\begin{array}{c}\% \text { of } \\
\text { Variance }\end{array}$ & Cumulative $\%$ & \\
\hline 1 & 1.516 & 10.105 & 10.105 & 1.516 & 10.105 & 10.105 & 1.371 \\
\hline 2 & 1.432 & 9.547 & 19.651 & 1.432 & 9.547 & 19.651 & 1.333 \\
\hline 3 & 1.282 & 8.548 & 28.199 & 1.282 & 8.548 & 28.199 & 1.317 \\
\hline 4 & 1.215 & 8.102 & 36.301 & 1.215 & 8.102 & 36.301 & 1.253 \\
\hline 5 & 1.171 & 7.807 & 44.108 & 1.171 & 7.807 & 44.108 & 1.219 \\
\hline 6 & 1.131 & 7.541 & 51.649 & 1.131 & 7.541 & 51.649 & 1.184 \\
\hline 7 & 1.026 & 6.842 & 58.492 & 1.026 & 6.842 & 58.492 & 1.096 \\
\hline 8 & .990 & 6.600 & 65.092 & & & & \\
\hline 9 & .911 & 6.076 & 71.168 & & & & \\
\hline 10 & .808 & 5.386 & 76.554 & & & & \\
\hline 11 & .789 & 5.260 & 81.813 & & & & \\
\hline 12 & .775 & 5.167 & 86.981 & & & & \\
\hline 13 & .728 & 4.852 & 91.833 & & & & \\
\hline 14 & .657 & 4.377 & 96.210 & & & & \\
\hline 15 & .569 & 3.790 & 100.000 & & & & \\
\hline
\end{tabular}

Source: own computation from survey data, 2018

Note: variables from 1-15 are original variables used to extract components and they are defined in table A.2 below.

Table A.2: communalities of original variable

\begin{tabular}{||l|l||l|l|}
\hline \hline No & Constraints of households saving capacity & Initial & Extraction \\
\hline 2 & Lack of loan services and incentives & 1.00 & .645 \\
\hline 3 & Lack of collateral & 1.00 & .666 \\
\hline 4 & Lack of infrastructural services(road,electrity,water) & 1.00 & .536 \\
\hline 5 & Absence of accountability and transparency & 1.00 & .396 \\
\hline 6 & Prevalence of corruption and rent seeking & 1.00 & .550 \\
\hline 7 & $\begin{array}{l}\text { Use of planning to the future is not important because god knows the } \\
\text { future }\end{array}$ & 1.00 & .620 \\
\hline 8 & Enjoying with friends is good no matter how much money is spent & 1.00 & .690 \\
\hline 9 & Religious disciplines prohibit households saving and investment & 1.00 & .440 \\
\hline 10 & $\begin{array}{l}\text { Lack of well-designed programs of experience sharing and social } \\
\text { networking }\end{array}$ & 1.00 & .675 \\
\hline 11 & $\begin{array}{l}\text { Strategies and programs do not follow a system of community based } \\
\text { approach }\end{array}$ & 1.00 & .629 \\
\hline 12 & Almost half of my monthly income is spent for stimulants & 1.00 & .636 \\
\hline 13 & Giving money to a friend is always important & 1.00 & .637 \\
\hline 14 & Difficulty of using electronic systems of banking services & 1.00 & .595 \\
\hline 15 & Unable to know account opening requirement & 1.00 & .620 \\
\hline
\end{tabular}

Source: own computation from survey data, 2018. 


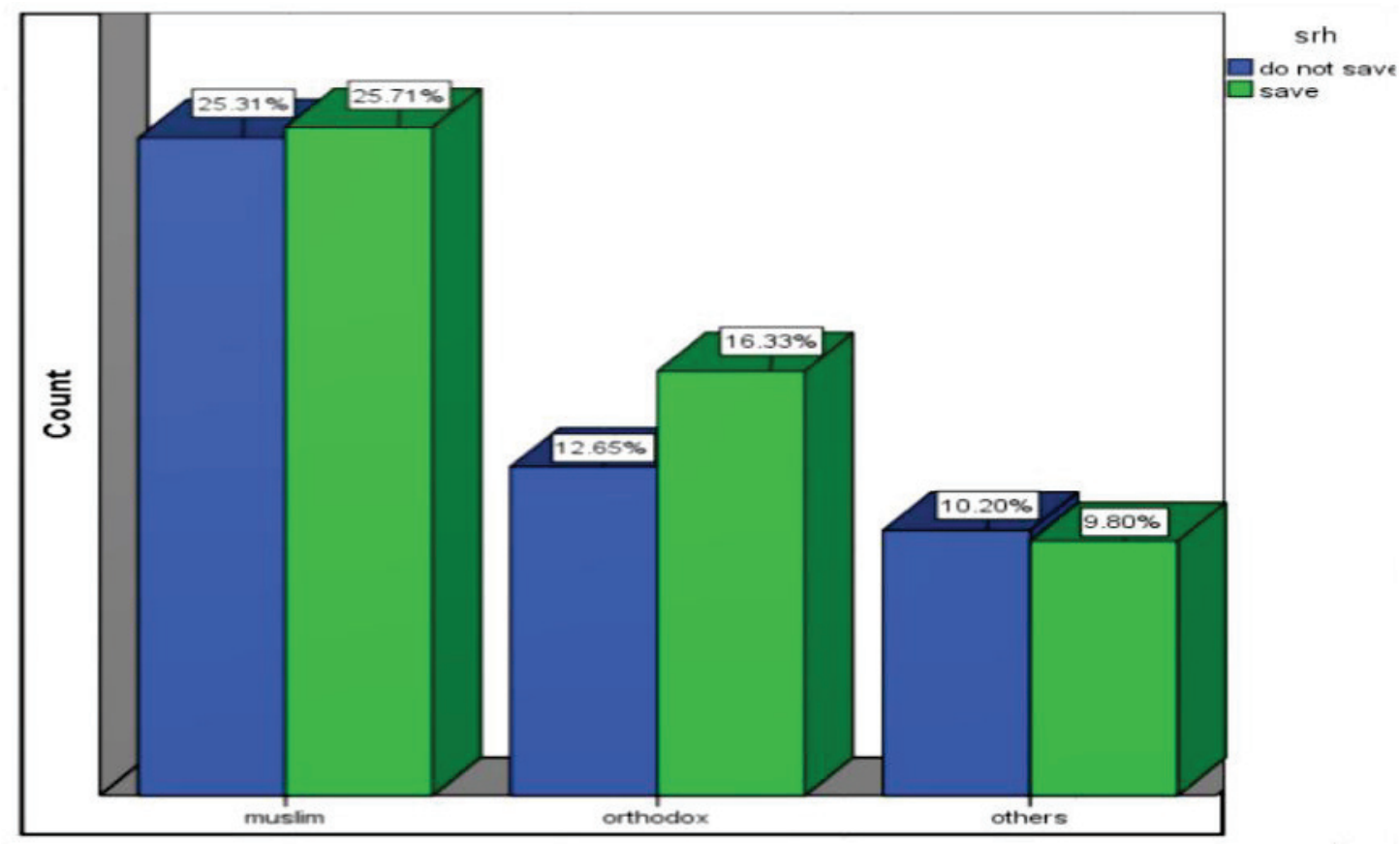

Figure 1. 2: Households religion and their saving response

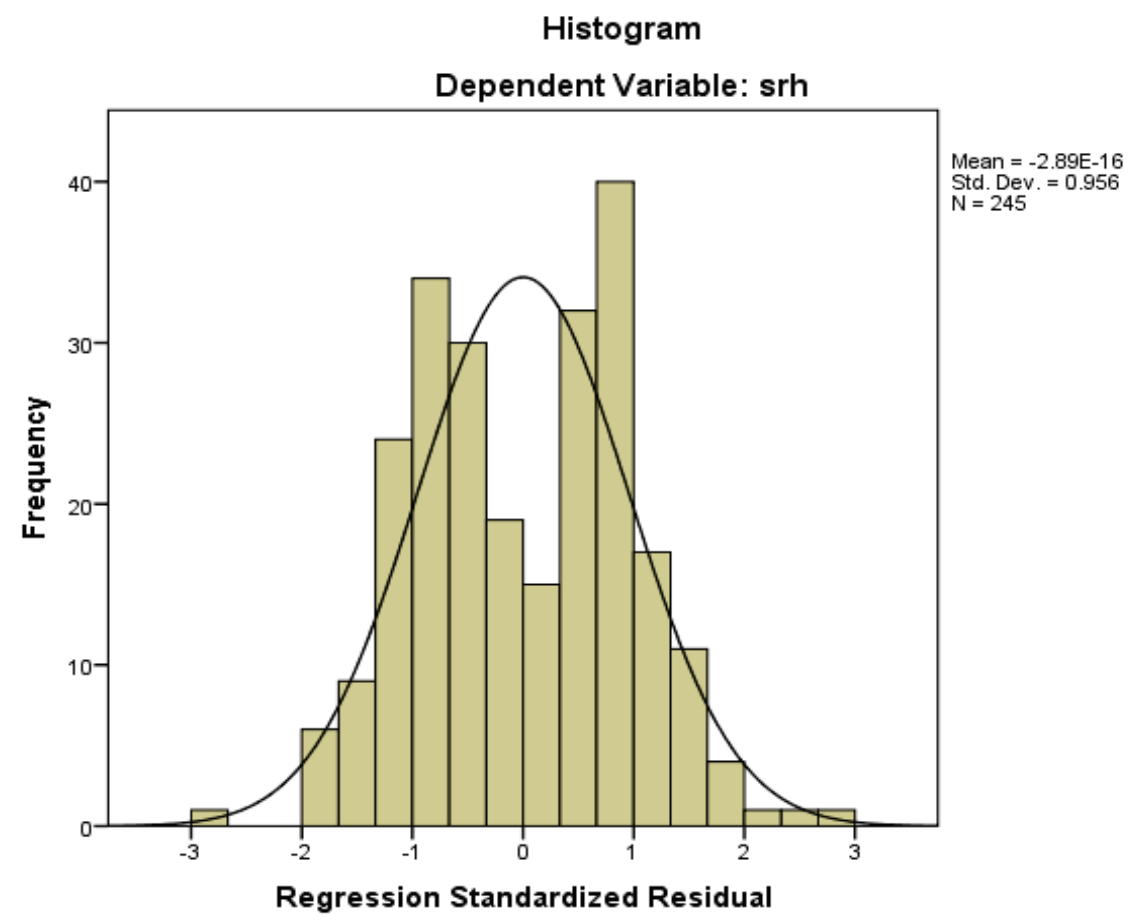

Figure 1.3 Normality tests: Determinants of households saving capacity 